\begin{tabular}{|l|l|l||}
\hline \multicolumn{2}{|c|}{ PublisherInfo } \\
\hline \hline PublisherName & $:$ & BioMed Central \\
\hline \hline PublisherLocation & $:$ & London \\
\hline \hline PublisherImprintName & $:$ & BioMed Central \\
\hline \hline
\end{tabular}

\title{
Protective effect of pancreatitis-associated protein
}

\begin{tabular}{|c|c|c|}
\hline \multicolumn{3}{|c|}{ ArticleInfo } \\
\hline ArticleID & : & 4168 \\
\hline ArticleDOI & : & 10.1186/ccf-1999-2282 \\
\hline ArticleCitationID & : & 2282 \\
\hline ArticleSequenceNumber & : & 27 \\
\hline ArticleCategory & : & Paper Report \\
\hline ArticleFirstPage & : & 1 \\
\hline ArticleLastPage & : & 3 \\
\hline ArticleHistory & : & $\begin{array}{ll}\text { RegistrationDate } & : \text { 1999-11-19 } \\
\text { OnlineDate } & : 1999-11-19\end{array}$ \\
\hline ArticleCopyright & : & Current Science Ltd1999 \\
\hline ArticleGrants & : & \\
\hline ArticleContext & : & 1305422 \\
\hline
\end{tabular}




\section{Keywords}

Acute phase response, acute respiratory distress syndrome, neutrophils

\section{Comments}

This paper provides another piece in the jigsaw puzzle of inflammatory and anti-inflammatory mediators. What remains to be seen is whether these effects occur in more complex models.

\section{Introduction}

Severe pancreatitis is associated with lung injury. This lung injury is due to the release of inflammatory mediators resulting in capillary leak and pulmonary oedema. During acute pancreatitis, a secretory protein known as pancreatitis-associated protein (PAP) is secreted and the concentration of PAP correlates with the severity of the disease. High levels of PAP have also been shown to be associated with improvements in outcome, at least in rats.

\section{Aims}

To evaluate the effect of PAP in leucocyte induced lung injury. The effects of PAP on pulmonary vascular resistance, oedema formation and the synthesis of thromboxane $\mathrm{A}_{2}\left(\mathrm{TxA}_{2}\right)$ were investigated.

\section{Methods}

Isolated perfused rabbit lungs were mounted on a weight transducer. Because of the constant flow of perfusate, changes in perfusion pressure directly reflect changes in pulmonary vascular resistance. Rat PAP was prepared from animals in which pancreatitis had been induced, and was extracted by affinity chromatography. Thirty lung preparations were then randomly assigned to receive either PAP only, be submitted to an inflammatory response with $N$ formyl-Met-Leu-Phe (fMLP) only, or two different doses 
of PAP followed by activation of leucocytes with fMLP. TxA 2 activation was then measured via the accumulation of the metabolite thromboxane $\mathrm{B}_{2}\left(\mathrm{TxB}_{2}\right)$. Weight gain of the organ preparation and mean pulmonary artery pressure (mpap) were recorded.

\section{Results}

The lung preparations exposed to PAP only did not exhibit any gain in weight, $\mathrm{TxB}_{2}$ release, or change in mpap. Leucocyte activation led to increases in mpap of $26 \pm 13 \mathrm{~mm} \mathrm{Hg}$ in the controls. This was attenuated to $15 \pm 7 \mathrm{~mm} \mathrm{Hg}$ with the lower dose of PAP and $9 \pm 4 \mathrm{~mm} \mathrm{Hg}$ with the higher dose. Weight gain was reduced from $9 \mathrm{~g}$ to either $2 \mathrm{~g}$ or $1 \mathrm{~g}$ at the different doses of PAP. TxB 2 levels showed similar diminution following leucocyte activation after administration of PAP.

\section{Discussion}

PAP is synthesised during acute pancreatitis and the level of PAP correlates with both the severity of disease and increased survival in rats. This experiment demonstrated that clinically relevant amounts of PAP show protective effects in preventing the leak in pulmonary vasculature and attenuating the rise in mpap. The reduction in mpap may be secondary to the fact that release of TxA2, a potent pulmonary vasopressor, is attenuated by PAP. Potential problems with the study are the applicabilty of an isolated organ study to the situation in vivo, and the fact that rat PAP was used in rabbits (rabbit PAP has yet to be sequenced).

\section{References}

1. Heller A, Fiedler F, Schmeck J, Luck V, Iovanna JL, Koch T: Pancreatitis-associated protein protects the lung from leukocyte-induced injury. Anesthesiology. 1999, 91: 1408-1414.

This PDF file was created after publication. 